\title{
Dociekania
}

\section{Chaos i porządek archiwum}

Paweł Zajas

TEKSTY DRUGIE 2021, NR 2, S. 227-242

DOI: 10.18318/td.2021.2.14 | ORCID: 0000-0001-6041-297X

1.

Jeffrey J.Williams, zapytany przed kilku laty o przyszłość filologii po erze teorii, przepowiadał nadejście epoki archiwum. Radosnemu aktowi dowartościowania archiwaliów wśród młodego pokolenia literaturoznawców towarzyszy, jego zdaniem, nierzadko nazbyt emfatyczne podejście do rękopisów i dokumentów, jak gdyby samo ich dotknięcie oferowało bezpośredni dostęp do historii literatury. Williams diagnozował, w analogii do opisanego przez Rolanda Barthes'a „efektu rzeczywistości”, „efekt historyzacji”: badacz ogarnięty gorączką archiwalną wskazuje w autorytarnym geście na przypis, który dokumentuje jego żmudną pracę w spuściźnie danego autora'.

Przekonanie o niemal zmysłowej wartości rękopisów pojawiło się już w opublikowanym w 1889 roku, bez mała założycielskim dla późniejszej instytucjonalizacji

1 J.J. Williams The little magazine and the theory journal: a response to Evan Kindley's „Big Criticism”, "Critical Inquiry” 2013 no. 2, s. 411.
Artykuł powstał

w ramach realizacji projektu badawczego $\mathrm{nr}$ 2019/33B/HS2/00017, sfinansowanego ze środków Narodowego

Centrum Nauki.
Paweł Zajas - prof. na Wydziale Anglistyki Uniwersytetu im. Adama Mickiewicza w Poznaniu oraz badacz stowarzyszony (research fellow) na University of Pretoria (RPA). W obszarze jego zainteresowań znajdują się kwestie dotyczące transferu oraz socjologii literatury. 
literackich archiwów, tekście Wilhelma Diltheya Archive für Literatur. Dilthey zauważał, że wszelkie niepublikowane świadectwa - korespondencje, szkice, luźne notatki, dzienniki - „ustąpiły w ciemność, pozostawiając po sobie jedynie czyny i słowa". Podstawowym zadaniem historiografii było jego

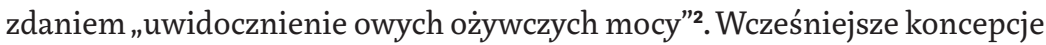
- na przykład przemyślenia Friedricha Schellinga dotyczące ewentualnych pośmiertnych edycji własnych dzieł, tudzież starania Ludwiga Tiecka o editio posthuma pism przyjaciół - koncentrowały się na konwersji rękopiśmienniczego archiwum w formę druku³. Dilthey formułował natomiast nową tradycję rekonwersji ${ }^{4}$, wskazując na wagę archiwaliów dla poznania "duszy” autora: w przeciwieństwie do „odosobnionych" i „zimnych" wydań książkowych „materiał rękopiśmienny oferuje dowody źródłowe, rozlewa kolor, ciepło i doznania życiowe na niezliczone siły", które odegrały rolę w powstaniu tekstu ${ }^{5}$.

W swoim manifeście programowym Dilthey nie czynił rozróżnienia na roboczy porządek pozostawionych przez twórcę manuskryptów oraz ich późniejszy porządek archiwalny. Również dzisiaj znaczna część literaturoznawców udaje się do archiwum z takim samym nastawieniem, z jakim czynili to historycy przed ponad stu laty. W zgromadzonych tam dokumentach spodziewają się uzyskać niezapośredniczony wgląd w proces twórczy, poszukują nieopublikowanych utworów, informacji dotyczących biografii, nowych kontekstów interpretacyjnych. Zasiadają w specjalnie przygotowanych czytelniach, a udostępniane przez archiwariuszy przechowywane w skrzynkach lub teczkach oryginały zdają się w ich przekonaniu emanować duchem historii. Badacze rzadko zadają sobie pytanie, w jaki sposób konkretne dokumenty trafily do archiwum oraz jak przebiegały procesy sortowania i katalogowania, dzięki którym stały się dostępne dla późniejszych interpretatorów.

2 W. Dilthey Archive für Literatur, w: tegoż Zur Geistesgeschichte des 19. Jahrhunderts. Portraits und biographische Skizzen, Quellenstudien und Literaturberichte zur Theologie und Philosophie im 19. Jahrhundert, hrsg. von U. Herrmann, Vandenhoek \& Ruprecht, Göttingen 1970, s. 4. Jeśli nie podano inaczej, cytaty podaję $w$ moim przekładzie.

3 F. Schelling Übersicht meines künftigen schriftlichen Nachlasses, "Kant-Studien" 1959/1960 Nr. 51, s. 14-20; M. Zybura Ludwig Tieck als Übersetzer und Herausgeber. Zur frühromantischen Idee einer "deutschen Weltliteratur", Winter, Heidelberg 1994, s. 147-199.

C. Spoerhase Neuzeitliches Nachlassbewusstsein. Über die Entstehung eines schriftstellerischen, archivalischen und philologischen Interesses an posthumen Papieren, w: Nachlassbewusstsein. Literatur, Archiv, Philologie, hrsg. von K. Sina, C. Spoerhase, Wallstein, Göttingen 2017, s. 36.

5 W. Dilthey Archive für Literatur, s. 5. 
W niniejszym artykule omawiam wybrane, zaczerpnięte z niemieckich doświadczeńlekturowych i instytucjonalnych, przykłady praktyk epistemicznych związanych z przeniesieniem dokumentów z miejsca ich wytworzenia pod reżim archiwum literackiego. W pierwszym kroku argumentacyjnym poruszam problematykę elementarnej formy przekazu przedmiotowego, jakim jest spuścizna autorska (Nachlass) ${ }^{6}$. W kroku drugim analizuję transpozycję produkcyjnego archiwum wydawniczego do formy archiwum literackiego. W końcu podsumowuję, porządkując poszczególne poziomy strukturyzacji i interpretacji archiwaliów, które w znacznym stopniu warunkują produkcję wiedzy. Przyglądając się procesom transpozycji i transgresji, porównanym przez Jürgena Thalera z opisaną przez Claude'a Levi-Straussa opozycją „,surowe" (stan natury) i "gotowane" (stan kultury) ${ }^{7}$, stawiam teoretyczne i metodologiczne pytania o konsekwencje praktyk archiwistycznych dla socjologii literatury. Czynię to w formie, w jakiej Bruno Latour i Steve Woolgar przedmiotem swoich prekursorskich dociekań uczynili przestrzeń laboratorium (a nie wyniki uzyskanych w nim badań) ${ }^{8}$, ponieważ to właśnie topografia/ tektonika zasobów archiwalnych reguluje dostępność informacji, podczas gdy mechanizmy decydujące o tym, co w archiwum jest widoczne, a co nie, pozostają poza zasięgiem wzroku.

\section{2.}

Czym jest przekazana do archiwum spuścizna autorska, tak pożądany przez wielu badaczy Nachlass, uwidaczniający, jak chciał Dithley, ,ożywcze moce” twórcy? Części składowe trudno przekładalnego na inne języki i znajdującego się w użyciu dopiero od wieku XVIII złożenia - "nach” w znaczeniu post mortem oraz "lassen” w rozumieniu „oddawać” - odnoszą się do takich pojęć, jak własność, osoba oraz wola. Awansowały one do rangi naczelnych kategorii mieszczańskiego liberalizmu i jako takie były niejednokrotnie

6 Por. Erbe. Übertragungskonzepte zwischen Natur und Kultur, bearbeitet von S. Weigel, S. Willer, B. Jussen, Suhrkamp, Berlin 2013; S. Willer Erbfälle. Theorie und Praxis kultureller Übertragung in der Moderne, Wilhelm Fink, Paderborn 2014.

7 J. Thaler Vom Rohen zum Gekochten: zur Ordnung des Nachlasses, w: Archive für Literatur. Der Nachlass und seine Ordnungen, hrsg. von P.-M. Dallinger, G. Hofer, B. Judex, de Gruyter, Berlin 2018, s. 89-90.

8 B. Latour, S. Woolgar Laboratory Life. The Construction of Scientific Facts, Princeton University Press, Princeton, NJ 1979. 
przedmiotem analiz w obszarze filozofii prawa (Hegel) czy historiografii (Droysen) ${ }^{9}$. Należy zauważyć, iż w kulturo- oraz literaturoznawczej literaturze przedmiotu rzadko pojawiają się propozycje, które pozwoliłyby na systematyczny namysł nad fenomenem Nachlass w ujęciu całościowym. W ramach badań nad kulturą materialną analizowane są społecznohistoryczne aspekty wybranych przedmiotów, z kolei dociekania na temat związków między literaturą a kulturą materialną koncentrują się na literackiej reprezentacji artefaktów ${ }^{10}$.

Struktura Nachlass jest determinowana przez czynniki zarówno wewnętrzne, jak i zewnętrzne. Te pierwsze mają podstawowy wpływ na topologię spuścizny autorskiej i są związane ze stosunkiem właściciela do wytworzonych/zgromadzonych przez niego dokumentów. Owego stosunku nie można w prosty sposób wyrazić poprzez obowiązujący w kodeksie cywilnym termin „władania rzeczą" (Sachherrschaft) ${ }^{11}$, ponieważ wyklucza on możliwość całkowicie biernej relacji między autorem a np. rozmaitymi przedmiotami o funkcji komemoracyjnej (pamiątkami, zdjęciami, zaproszeniami etc.). Owej relacji przypisuje się wartość nierzadko post factum. Pracując z tego typu dokumentami, należy zatem pamiętać o czynnej roli archiwariuszy, którzy podejmują decyzję o włączeniu poszczególnych artefaktów na mocy arbitralnej oceny ich wartości.

Zachowane przez autorów dokumenty pełnią w większości przypadków funkcję pragmatyczną, są medium komunikowania się ze światem zewnętrznym (korespondencja) lub formą autokomunikacji (notatki, projekty, dzienniki, poszczególne wersje manuskryptów). To rodzaj zewnętrznej pamięci, którą za Niklasem Luhmanem można określić mianem osobistego „systemu semantycznego". Chodzi bowiem o spostrzeżenia, które zostały „utrwalone $\mathrm{w}$ formie zapisu, a tym samym uznane za godne zachowania celem powtórzenia"12. Afektywny wymiar Nachlass dotyczy również wszelkich innych obiektów „utrwalających zmysłowe wrażenia dla ich ponownego użycia”³. Całość

9 U. von Bülow Papierarbeiter. Autoren und ihre Archive, Wallstein, Göttingen 2018, s. $19-20$.

10 Por. Handbuch Materielle Kultur. Bedeutungen, Konzepte, Disziplinen, hrsg. von S. Samida, M.K.H. Eggert, H.P. Hahn, J.B. Metzler, Stuttgart 2014. K. Zaradkiewicz Romańska teoria posiadania a kodeks cywilny, "Studia luridica” 2016 nr 64, s. 111. N. Luhmann Die Wissenschaft der Gesellschaft, Suhrkamp, Frankfurt am Main 1990, s. 107.

13 N. Luhmann Das Recht der Gesellschaft, Suhrkamp, Frankfurt am Main 1993, s. 126; por. T. Habermas Geliebte Objekte, Suhrkamp, Frankfurt am Main 1999. 
przechowywanych przez autora materiałów piśmiennych i niepiśmiennych jest rodzajem „pamięci funkcjonalnej”, kształtowanej przez aktywny akt gromadzenia i podlegającej ciągłej ewaluacji. Różni się ona znacząco od "pamięci magazynowanej", gdyż tam pasywnym aktem gromadzenia rządzi przypadek ${ }^{14}$. Termin ten można odnieść do archiwów autorskich pozbawionych narzuconego z góry porządku. Nadanie indywidualnemu zbiorowi rangi pamięci funkcjonalnej wymaga wprowadzenia systemu. Sposób, w jaki niektórzy autorzy umieszczali wytworzone przez siebie dokumenty w pudełkach, teczkach, segregatorach lub folderach cyfrowych oraz je opisywali, stanowi istotną wskazówkę dla późniejszej analizy naukowej Nachlass.

Klasycznym przykładem auktorialnego, zainicjowanego przez samego autora, porządku przestrzennego jest archiwum Goethego. Weimarski klasyk określił topografię swojego gabinetu jako „w nieco nieuporządkowany sposób uporządkowaną, nieco cygańską"15. Karl Ludwig von Knebel utyskiwał już wcześniej, że poeta „wyciągał własne manuskrypty ze wszystkich zakątków pokoju"16. Pozostaje jednak faktem, że bezpośrednio po przeprowadzce do Weimaru w 1775 roku i podjęciu pracy w administracji Tajnego Konsylium Goethe zaczął organizować własną pracę w kancelaryjnym stylu: pomoce biurowe w postaci papierowych toreb i teczek, a także klasyfikacyjne techniki prowadzenia akt porządkowały zarówno opublikowane już teksty, jak i niepublikowane projekty ${ }^{17}$. W latach 1792-1795 zainicjował w okazałym domu na Frauenplan powstanie warsztatu pisarskiego, który zoptymalizował pracę wykonywaną przez niego oraz jego współpracowników. W końcu wszystkie manuskrypty zostały w 1822 roku powiązane w paczki, posegregowane w przeznaczonych do tego celu szafach oraz opisane w repertorium. Dwa lata później całość „,archiwum literackiego” została przeniesiona do „pokoju

14 A. Assmann Funktionsgedächtnis und Speichergedächtnis - Zwei Modi der Erinnerung, w: Generation und Gedächtnis. Erinnerungen und kollektive Identitäten, hrsg. von K. Platt, M. Dabag, VS Verlag für Sozialwissenschaften, Wiesbaden 1995, s. 169-185.

15 J.P.E. Eckermann Gespräche mit Goethe in den letzten Jahren seines Lebens, hrsg. von F. Bergemann, Bd. 1, Insel, Baden-Baden 1981, s. 307-308.

16 Karl Ludwig von Knebel do Friedricha Justina Bertucha, 11-14.12.1774, w: Goethes Gespräche. Biedermannsche Ausgabe, ergänzt und hrsg. von W. Herwig, Bd. 1, dtv, München 1998, s. 51.

17 E.R. Curtius Goethes Aktenführung, w: tegoż Kritische Essays zur europäischen Literatur, Frankce, Bern 1963, s. 57-69. 
ze sklepieniem"18, centralnego pomieszczenia domu. Autorefleksja Goethego, który „postrzegał siebie coraz mocniej w kategoriach historycznych”' znalazła wyraz w opublikowanej w 1823 roku na łamach czasopisma „Über Kunst und Altertum" rozprawie Archiv des Dichters und Schriftstellers. Archiwum Goethego było pionierskie nie tylko ze względu na leżące $u$ jego podstaw kryterium proweniencji oraz wolę możliwie pełnej inwentaryzacji wszystkich wytworzonych za życia rękopisów, lecz także z uwagi na to, że archiwalna świadomość autora rozwijała się poniekąd in actu, w ramach bezpośredniej relacji z najbliższymi współpracownikami oraz zgodnie z antycypowanym $\mathrm{w}$ danym momencie przyszłym wykorzystaniem spuścizny ${ }^{20}$. Nowatorska była również interioryzacja dokumentów, dzięki której archiwum literackie weimarskich klasyków prezentowało, jak trafnie to ujął Herman Grimm, "przestrzenie mieszkalne ich pism"21. Podstawowym dokumentem roboczego rozmieszczenia manuskryptów, zbioru obiektów, pisarskich utensyliów czy suwenirów stały się sporządzone przez współpracowników kilka dni po śmierci autora Acta den pp. Von Goethe'schen Nachlass betr. (Akta dotyczące spuścizny Goethego), stanowiące szczegółową inwentaryzację wszystkich szuflad, regałów i szaf ${ }^{22}$.

Paradygmatyczny przykład Nachlass Goethego ilustruje z jednej strony mechanizmy konstrukcji „pamięci funkcjonalnej”, z drugiej zaś autorskiej

18 J.W. Goethe Tagebuch, 9.5.1824, cyt. za: Ch. Holm Raumordnungen des Nachlasses. Das „litterarische Archiv" in Goethes Wohnhaus, w: Nachlassbewusstsein. Literatur, Archiv, Philologie 1750-2000, hrsg. von K. Sina, C. Spoerhase, Wallstein, Göttingen 2017, S. 132.

J.W. Goethe do W. von Humboldta, 1.12.1831, cyt. za: tamże, s. 133.

Ch. Holm Raumordnungen des Nachlasses, s. 142.

H. Grimm Die Zukunft des Weimarischen Goethe-Schiller-Archivs, "Deutsche Rundschau” 1898 Nr. 95, s. 436.

H. Wahl Goethes Arbeitszimmer in der Stunde seines Todes, "Goethe. Viermonatsschrift der Goethe-Gesellschaft" 1942 Nr. 7, s. 4-16. Problematykę interioryzacji poszczególnych zbiorów podejmuje się obecnie w ramach rozmaitych projektów badawczych. Latourowska metodyka etnograficzna w badaniach nad produkcją wiedzy jest realizowana przez konsekwentny namysł nad tektoniką i chronologią archiwów i bibliotek autorskich. Zob. G. Ecker Literarische Kramschubladen. Portraits - Museen - Zwischenspeicher, "Zeitschrift für deutsche Philologie” 2006 Nr. 125, S. 19-31; A. te Heesen, A. Michels auf/zu. Der Schrank in den Wissenschaften, Akademie-Verlag, Berlin 2007; Ch. Holm Goethes Gewohnheiten. Konstruktion und Gebrauch der Schreibund Sammlungsmöbel im Weimarer Wohnhaus, w: Weimarer Klassik. Kultur des Sinnlichen, hrsg. von S. Böhmer, Ch. Holm, V. Spinner, Deutscher Kunstverlag, Berlin, München 2012, s. 118-125; Autorschaft und Bibliothek. Sammlungsstrategien und Schreibverfahren, hrsg. von S. Höppner, C. Jessen, J. Münkner, Wallstein, Göttingen 2018. 
autoprezentacji. Nie inaczej rzecz się przedstawia u autorów XX-wiecznych. Ernst Jünger porządkował swoją pamięć funkcjonalną w formie alfabetycznych dossier korespondencyjnych, Uwe Johnson skonstruował podczas pracy nad czterotomowym cyklem powieściowym Jahrestage (1970-1983) systematyczny zbiór wycinków prasowych. Szczególnym przykładem organizacji i dokumentacji procesu twórczego są słynne kartoteki takich autorów, jak Jean Paul, Arno Schmidt, Walter Kempowski, Hans Blumenberg, Friedrich Kittler, Niklas Luhmann czy Aby Warburg, które w połączeniu z zachowanymi rękopisami i bibliotekami pozwalają na niemal kompletną rekonstrukcję procesu twórczego ${ }^{23}$.

Podczas gdy dokumentacja gromadzona przez wymienionych pisarzy i filozofów nie była prymarnie adresowana do potomności, to w przypadku Nachlass W.G. Sebalda mamy do czynienia z planową konstrukcją autorskiego wizerunku. Całość tego niezwykle obszernego zbioru wykazuje cechy starannej selekcji pod kątem przyszłej recepcji. Pisarz, który sam wielokrotnie pracował w archiwach, a przechowywane w nich zasoby czynił w powieściach przedmiotem metafikcjonalnej refleksji, usunął z pozostawionych rękopisów wszelkie ślady autobiograficzne. Powodem nie była bynajmniej osobista skromność. Sebald niejednokrotnie przecież transformował własną postać do formy „dokumentarnej fikcji”, wyrażając w niej nader osobistą „melancholijną pozycję"24. Być może był nader świadom, w jaki sposób redaktorzy wydań zbiorowych oraz interpretatorzy obchodzą się z tego rodzaju materią. To właśnie spod jego pióra wyszły eseje poświęcone Adalbertowi Stifterowi i Franzowi Kafce, w których Sebald obficie korzystał z zachowanych listów i dzienników w celu połączenia dzieła z psychologią twórcy ${ }^{25}$. Przyszłych pokoleń badaczy Sebald pozbawił tego typu tworzywa, przekazując jedynie liczne materiały, wypisy i notatki będące wyrazem czysto estetycznej egzystencji.

23 Zettelkästen. Maschinen der Phantasie, hrsg. von H. Gfrereis, E. Strittmatter, Deutsche Schillergesellschaft, Marbach am Neckar 2013.

24 W. Mason Mapping a life: a review ofW.G. Sebald, "The American Book Review" 1999 no. 5/6, s. 20; M. Niehaus W.G. Sebalds sentimentalische Dichtung, w: W.G. Sebald. Politische Archäologie und mechancholische Bestelei, hrsg. von M. Niehaus, C. Öhlschläger, Erich Schmidt, Berlin 2006, s. $173-187$.

W.G. Sebald Bis an den Rand der Natur. Versuch über Stifter, w: tegoż Die Beschreibung eines Unglücks. Zur österreichischen Literatur von Stifter bis Handke, Residenz-Verlag, Salzburg, Wien 1985, s. 15-37; tegoż Dr. K. na kąpielach w Rivie, w: tegoż Czuję. Zawrót głowy, przeł. M. Łukasiewicz, W.A.B., Warszawa 2010, s. 151-180. 
Problem ten jest jeszcze wyraźniej widoczny w wypadku dokumentów przekazywanych archiwom literackim przez żyjących pisarzy w formie Vorlass, owego „wyjątkowego sposobu autoprezentacji”, dzięki któremu „własna teraźniejszość awansuje do rangi jutrzejszej przeszłości, a jeszcze świeży atrament przeistacza się w pośmiertny rękopis"26. Warto przypomnieć, że choć w niemieckim obszarze językowym termin „Vorlass” był jeszcze na początku obecnego stulecia neologizmem wymagającym komentarza ${ }^{27}$, to np. w Stanach Zjednoczonych praktyka negocjacji między autorami a bibliotekami uniwersyteckimi należała do uzusu archiwalnego już w latach 40. XX wieku, o czym świadczą chociażby pertraktacje prowadzone z Tomaszem Mannem przez Uniwersytet Yale ${ }^{28}$. Dość aktualnym przykładem szczegółowo zaplanowanej „precepcji archiwalnej”29 ze strony autora jest medialnie zainscenizowana przez Petera Handkego sprzedaż kilkudziesięciu osobistych notatników Deutsches Literaturarchiv Marbach.

\section{3.}

Powyższe rozważania dotyczyły czynników w e w n ę tr z ny ch mających wpływ na strukturę spuścizny autorskiej, związanych ze stosunkiem właściciela do wytworzonych/zgromadzonych przez niego dokumentów. W tym miejscu należy je uzupełnić o kilka uwag na temat czynników z e w n ę tr z ny c h. Przede wszystkim już sama objętość Nachlass jest warunkowana okolicznościami materialnymi, a nierzadko politycznymi. Najdobitniej dowodzą tego archiwa emigrantów. Prześladowany przez nazistów Karl Löwith, uciekający przez Włochy i Japonię do USA, czy zmarły na uchodźstwie we Francji Joseph Roth pozostawili po sobie nieliczne rękopisy. Podobnie rzecz się miała z twórcami pozbawionymi przez dłuższy okres stałego miejsca zamieszkania. Intuicyjnie wymienić można kolejne czynniki: zniszczenia wojenne, ingerencje cenzury/służb bezpieczeństwa oraz konfiskaty mienia (szczególnie dotkliwe w odniesieniu do autorów tworzących w warunkach niedemokratycznych), decyzje spadkobierców, w końcu (paradoksalnie) politykę instytucji

26 C. Spoerhase Neuzeitliches Nachlassbewusstsein, s. 48.

27 L. Müller Vorlass. Die Berliner Akademie der Künste kauft das Archiv Christa Wolfs, ,"Süddeutsche Zeitung", 14.1.2002, s. 18.

Th. Mann Tagebücher1949-1950, hrsg. von I. Jens, Fischer, Frankfurt am Main 1991, S. 307.

29 H. Lübbe Archivarische Gewaltenteilung, w: Handbuch Archiv. Geschichte, Aufgaben, Perspektiven, hrsg. von M. Lepper, U. Raulff, J.B. Metzler, Stuttgart 2016, s. 11. 
archiwalnych - decyzja o nieprzejęciu dokumentów skutkuje w wielu wypadkach ich zniszczeniem ${ }^{30}$. O ile bowiem akta administracji państwowej są automatycznie przejmowane $\mathrm{w}$ formie masy archiwalnej przez powołane do tego celu placówki, a następnie klasyfikowane/poddawane kasacji zgodnie ze szczegółowymi instrukcjami kancelaryjnymi, o tyle morfogeneza Nachlass jest warunkowana również przez same archiwa literackie.

Ostatnia kwestia wymaga choćby skrótowego rozwinięcia.Zarówno archiwistyczne, jak i szerzej formułowane (np. kulturoznawcze) definicje Nachlass określają jego charakter w sposób dość rozbieżny. Jeśli pod pojęciem tego typu zasobu będziemy rozumieć „pośmiertne osobiste rejestry danej osoby" ${ }^{\prime \prime}$, to poza jego nawiasem pozostaną wszelkie obiekty niepiśmienne. Inne próby definicyjne wydają się z kolei zbyt inkluzyjne. Na przykład oficjalne Regeln zur Erschließung von Nachlässen und Autographen (Zasady udostępniania spuścizn i rękopisów, RNA), opracowane na zlecenie Deutsche Forschungsgemeinschaft, stanowią, że termin „spuścizna autorska w ścisłym znaczeniu słowa" (echterNachlass) oznacza "sumę wszystkich materiałów znajdujących się w posiadaniu osoby w okresie jej życia". W przypadku pośmiertnej kooptacji materiałów przez osoby trzecie mamy do czynienia ze spuścizną "wzbogaconą" lub „poszerzoną” (angereicherter/erweiterter Nachlass) ${ }^{32}$. Aleida Assmann pisze zaś na marginesie uwag dotyczących roli muzeów/archiwów w tworzeniu pamięci kulturowej o „rzeczowym kontekście przeżytego życia”33.

W praktyce poszczególne archiwa literackie definiują swoją politykę akwizycji indywidualnie. Kierownik działu rękopisów Deutsches Literaturarchiv Marbach Ulrich von Bülow opisuje ów proces następująco:

Przy pojawiającym się każdorazowo pytaniu, co stanowi istotną część Nachlass, decydującą rolę odgrywa kwestia własności nie intelektualnej, lecz materialnej. W archiwistycznym rozumieniu terminu Nachlass zawiera oprócz na przykład otrzymywanych przez autora listów również

U. von Bülow Nachlässe, w: tamże, s. 150-151.

E.G. Franz Einführung in die Archivkunde, WBG, Darmstadt 1993, s. 67.

Regeln zur Erschließung von Nachlässen und Autographen (RNA). Betreut von der Staatsbibliothek zu Berlin - Preußischer Kulturbesitz und der Österreichischen Nationalbibliothek Wien, http:// kalliope-verbund.info/_Resources/Persistent/5bf5cd96ea4448bfec20caf2e3d3063344d76b58/ rna-berlin-wien-mastercopy-08-02-2010.pdf (14-09.2020).

A. Assmann Der lange Schatten der Vergangenheit. Erinnerungskultur und Geschichtspolitik, C.H. Beck, München 2006, s. 54 . 
dokumenty wytworzone przez osoby postronne. [...] Nie licząc unikatowych rękopisów, w skład Nachlass wchodzą rozmaite druki, biblioteki, obrazy i obiekty (przedmioty pamiątkowe), przejmowane zazwyczaj zaledwie w ograniczonej objętości. [...] Decyzja o zakupie danego Nachlass przez konkretne archiwum jest zależna od wielu czynników: z jednej strony od woli właściciela, z drugiej zaś od profilu instytucji oraz jej możliwości personalnych, finansowych i przestrzennych. Kolekcjonerskie cele archiwum pełniącego funkcję przedsiębiorstwa usługowego dla nauki winny zostać przynajmniej orientacyjnie uzgodnione z polityką akwizycji pozostałych archiwów i bibliotek. [...] Najrozsądniejszym rozwiązaniem jest poprzedzenie akwizycji dokładną autopsją materiału. [...] Jeśli autor sam nie przekazał instytucji swojego Nachlass, w roli partnerów negocjacyjnych występują spadkobiercy. [...] Po zapadnięciu decyzji o przejęciu dokumentów ustalamy w porozumieniu z nimi jego zakres. Czasami sensowne jest przejęcie całości, $\mathrm{w}$ innych przypadkach zakup reprezentatywnego wyboru. Również w trakcie późniejszej inwentaryzacji mało istotne materiały podlegają selekcji, zwrotom lub, w porozumieniu ze spadkobiercami, kasacji. ${ }^{34}$

W kontekście powyższej wypowiedzi poniekąd automatycznie nasuwa się Foucaultowskie rozumienie kategorii archiwum („prawo tego, co może być powiedziane" ${ }^{\prime 35}$ ), które pozbawiło je, nie tylko na poziomie refleksji teoretycznej, atrybutu „dokumentacyjnej pasywności” $i$,konserwatorskiej niewinności"36. Archiwariusze podejmują kluczowe decyzje dotyczące zarówno istnienia/nieistnienia dokumentów, jak i kontekstu, w jakim użytkownik otrzyma wyselekcjonowane dokumenty. Do ich podstawowych kompetencji należy bowiem decyzja o zachowaniu pierwotnego porządku przejętego zbioru lub jego przekształcenie zgodnie z obowiązującymi w danym archiwum regulacjami. Klaus Kastberger ujął ów nieodzowny skądinąd proces transpozycji w następujący sposób:

Każdy, kto kiedykolwiek przekroczył progi współczesnego archiwum literackiego i miał wgląd w zasoby uporządkowane zgodnie z obowiązującymi

U. von Bulow Papierarbeiter, s. 16-17. 
w dzisiejszych czasach zasadami, zdaje sobie sprawę, że forma ich uporządkowania niewiele ma wspólnego z pierwotnym usytuowaniem i łączeniem materiałów w miejscu, w którym odbywała się produkcja literatury. Być może Dilthey inaczej wyobrażał sobie przyszłe działania archiwów i archiwariuszy. We współczesnym archiwum nie otrzymujemy jednak dostępu do typologii warsztatu pisarza. [...] Jego porządek jest funkcjonalny: topologie domu, mieszkania, biura, biurka czy wewnętrzna architektura komputera wyznaczają położenie materiału literackiego i oferują możliwości jego przechowywania. Rozmaite papiery odkładane są do szaf, regałów, skrzyń, szuflad, przegródek, segregatorów, teczek oraz pudełek najczęściej wówczas, gdy autor zakończył już pracę nad dziełem lub też zdecydował się na szerzej zakrojone porządki. [...] W archiwum nie natrafimy na żaden ślad owych różnorodnych systematyzacji. Fotografia gabinetu nierzadko może nam dostarczyć więcej informacji na temat pisarskiego warsztatu niż uporządkowany w archiwum Nachlass. W mieszkaniu pisarza lub pisarki panuje bowiem czasami po prostu chaos. $^{37}$

\section{4.}

Powyższą refleksję Kastbergera dotyczącą spuścizny indywidualnego autora można również odnieść do problemu transpozycji obszernych archiwów wydawniczych. Za ilustratywny casus może posłużyć w tym miejscu opracowanie kompletnego archiwum Suhrkamp Verlag. W 2009 roku zostało ono nabyte przez Deutsches Literaturarchiv Marbach (DLA) i figuruje tam obecnie pod nazwą Siegfried Unseld Archiv (SUA), upamiętniającą postać głównego edytora. SUA zawiera materiały z lat 1945-2002; dokumentację produkcyjną uzupełnia osobista korespondencja wydawców Petera Suhrkampa i Siegfrieda Unselda. Jego znaczenie wynika nie tyle z bezprecedensowej skali przejętych archiwaliów - ponad 20 tysięcy segregatorów oraz około 25 tysięcy książek ${ }^{38}$ - ile raczej z pozycji zajmowanej przez oficynę w drugiej połowie XX wieku, którą George Steiner opatrzył wymowną etykietą ,Suhrkamp Culture”. Listy

37 K. Kastberger Nachlassbewusstsein. Vorlass-Chaos und die Gesetze des Archivs. Am Beispiel von Friederike Mayröcker, w: Nachlassbewusstsein. Literatur, Archiv, Philologie, hrsg. von K. Sina, C. Spoerhase, Wallstein, Göttingen 2017, s. 416.

38 J. Bürger "Aber unsere große Entdeckung war... Siegfried Unseld". Ein erster Blick auf das Archiv der Verlage Suhrkamp und Insel, "J)ahrbuch der Deutschen Schillergesellschaft” 2010 Nr. 54, s. 16. 
oraz manuskrypty postaci kluczowych dla literatury i nauki ubiegłego stulecia czynią z SUA istotne źródło do badań nad praktyką wydawniczą, historią literatury i historią idei.

Dla socjologa literatury - zainteresowanego procesami przetwarzania i przekazywania wiedzy między aktorami pola wydawniczego, procesem produkcji i polityką publikacyjną - kluczową kwestią jest świadomość mechanizmów konwersji archiwum wydawnictwa (bieżącej dokumentacji przedsiębiorstwa) w formę archiwum wydawniczego, z właściwym dla niego porządkiem katalogowania. Archiwariusze obecni przy przekazywaniu i pakowaniu dokumentów w ówczesnej siedzibie Suhrkampa przy frankfurckiej Lindenstrasse określili stan dokumentacji mianem „chaosu"39. Papiery wypełniały każde wolne miejsce, logika ich przechowywania/dostępności była w dużej mierze znana jedynie pracownikom poszczególnych działów i podlegała przekształceniom wraz z rozwojem personalnym wydawnictwa (od 7 osób w 1957 do 145 w roku 200o). Trudne warunki logistyczne - w tym samym czasie trwał proces przenoszenia bieżącej dokumentacji oficyny do Berlina i proces przekazywania archiwaliów do DLA w Marbach - miały udaremnić próbę dokładnej inwentaryzacji ich ulokowania w przestrzeni willi. Segregatory przed zapakowaniem do transportu otrzymały zatem bieżący numer ewidencyjny oraz raczej intuicyjne oznaczenie przynależności do konkretnych działów. Choć trudno podawać w wątpliwość prezentowany przez archiwariuszy obraz olbrzymiej ilości papieru, którą w analogii do biomasy należałoby określić mianem "skryptomasy" ${ }^{\text {"40 }}$, to należy zauważyć, że z jednej strony dysymuluje on istnienie relacji między wewnątrzwydawniczymi praktykami komunikacyjnymi a oryginalną tektoniką dokumentacji, z drugiej zaś podkreśla potrzebę zamiany zastanego "chaosu” w „porządek”.

Za dość oczywistym przekształceniem przechowywanych w segregatorach dokumentów w zasoby archiwalne (przez oczyszczenie, usunięcie spinaczy, zszywek, plastikowych koszulek, sortowanie w teczkach bezkwasowych oraz typowych dla DLA zielonych kartonach, w końcu ich katalogowanie) skrywa się znacznie bardziej skomplikowana praktyka epistemiczna.

39 J. Bürger "Das Siegfried Unseld Archiv: Genese, Überlieferung und Erschließungszustand”, referat wygłoszony na konferencji „Suhrkamp und Osteuropa”, 25-27.10.2015, Deutsches Literaturarchiv Marbach.

40 U. Raulff Sie nehmen gern von den Lebendigen. Ökonomien des literarischen Archivs, w: Archivologie. Theorien des Archivs in Philosophie, Medien und Künsten, hrsg. von K. Ebeling, S. Günzel, Kadmos, Berlin 2009, s. 229. 
Przejmując zbiory Suhrkampa, DLA odeszło bowiem od obowiązującej dotychczas systematyki „porządkowania spuścizn literackich i autografów”, rozróżniającej trzy kategorie tekstów (manuskrypty, listy oraz przynależne materiały $)^{41}$. Powzięto mianowicie decyzję o zastosowaniu tzw. Verwaltungsstrukturprinzip - rozwiniętej zasady przynależności zespołowej, opierającej się na strukturze organizacyjnej wydawnictwa. W pierwszej fazie opracowywania zbiorów katalogowaniu poddano oznaczoną cyframi 01 korespondencję pionu kierowniczego oraz redaktorów (03). Pozostałe kategorie określono, zgodnie z przyjętą strukturą organizacyjną, jako: administracja i akta osobowe (02), produkcja (04), dystrybucja (05), reklama (06), prasa (07), prawa autorskie i licencje (08), marketing i odczyty (09), rachunkowość i kontrola finansowa (10).

W kontekście podanych informacji należy poczynić dwie uwagi. Pierwsza z nich dotyczy istoty przyjętej zasady przynależności zespołowej akt: choć poszczególne działy (01-10) odpowiadają planowi organizacji wydawnictwa, w tym wypadku mamy do czynienia z typem idealnym (w rozumieniu weberowskim) ${ }^{42}$, a więc z narzędziem heurystycznym, które archiwariusz wypracował w odniesieniu do świata rzeczywistego na potrzebny klasyfikacji jednostek archiwalnych. Stosując Verwaltungsstrukturprinzip transformuje on zastany we frankfurckiej willi wydawnictwa Suhrkamp "chaos” w „porządek” archiwum. Wprawdzie bez nadanej przez niego struktury poszczególne dokumenty nie byłyby widoczne i nie dawałyby się wyszukiwać, trzeba jednak pamiętać, że prezentowany potencjalnemu badaczowi elektroniczny katalog jest jednocześnie „produkującym fakty aktem performatywnym” ${ }^{\text {«3 }}$. Knut Ebeling i Stephan Günzel zauważają w tym kontekście:

Archiwum nie jest bynajmniej miejscem, do którego można się udać, aby odkryć fakty. Odbywa się w nim aktywny proces ich ciągłego przegrupowywania i permanentnej transformacji. Pojęcie archiwum jest tym

41 J. Meyer Erschließungsmodelle und die Bedürfnisse der Forschung. Das „Marbacher Memorandum" des Deutschen Literaturarchivs, w: Literaturarchiv und Literaturforschung. Aspekte neuer Zusammenarbeit, hrsg. von Ch. König, S. Seifert, Saur, München 1996, s. 186.

R. Mayntz Max Webers Idealtypus der Bürokratie und die Organisationssoziologie, w: Politologie und Soziologie. Otto Stammer zum 65. Geburtstag, hrsg. von J. Fijalkowski, VS Verlag für Sozialwissenschaften, Köln-Opladen 1965, s. 91-101.

43 C. Vismann Akten. Medientechnik und Recht, Fischer Taschenbuch, Frankfurt am Main 2000, s. 89 . 
samym tożsame z pojęciami wiedzy pozbawionej pochodzenia i kontyngencji prawdy. ${ }^{44}$

\section{5.}

Powyższe rozważania wymagają na koniec uporządkowania i podsumowania. We wstępie podkreślałem, że wiedza dotycząca skonstruowanego porządku archiwum jest literaturoznawcy, a w szczególności socjologowi literatury niezbędna. Badacz udający się do archiwum winien bowiem mieć świadomość, że ów porządek jest wynikiem wcześniejszych interpretacji. Możemy wyróżnić trzy następujące po sobie poziomy zabiegów interpretacyjnych.

(1) Na poziomie pierwszym należy umieścić czynniki wewnętrzne określające strukturę Nachlass. Zachodzącą w tym wypadku interpretację spuścizny określimy mianem auktorialnej, tj. takiej, która została przeprowadzona przez samego autora. Za paradygmatyczny uznałem w tym kontekście przypadek Goethego, który jako jeden z pierwszych, przynajmniej w historii literatury niemieckiej, dokonał instytucjonalizacji osoby autora poprzez nowatorski rodzaj polityki archiwalnej. Wskazałem, że XX-wieczni pisarze w coraz bardziej świadomy sposób sterowali „precepcją archiwalną” przez uprzednio zaplanowane sortowanie/katalogowanie dokumentów (ilustratywny jest tutaj przywołany przykład spuścizny Sebalda).

(2) Na drugim poziomie interpretacji usytuujemy czynniki zewnętrzne, m.in. zdarzenia losowe, zniszczenia wojenne, decyzje spadkobierców oraz politykę instytucji archiwalnych. Ta ostatnia ma istotne znaczenie dla zrozumienia morfogenezy zasobu archiwalnego. Badacz pracujący w archiwum winien w tym kontekście zwrócić szczególną uwagę na trzy kwestie. Pierwszą z nich jest kwestia akwizycji - decyzja o zakresie zakupionych/przejętych archiwaliów jest kluczowym elementem strukturyzującym późniejszy obiekt badań. Druga kwestia to selekcja i opracowanie przejętego materiału. Przykład Siegfried Unseld Archiv pokazuje, że samo stworzenie katalogu obszernego zasobu archiwum produkcyjnego nie jest jedynie uwidocznieniem tego, co było, lecz aktem interpretacji. W zastaną „,kkyptomasę" został wprowadzony porządek zgodny z tym, w jaki sposób archiwariusz wy o b ra ził s o bi e codzienne funkcjonowanie wydawnictwa. Dla pracującego w archiwum historyka idei ów fakt pozostaje być może mało istotny, natomiast dla

44 K. Ebeling, S. Günzel Einleitung, Archivologie. Theorien des Archivs in Philosophie, Medien und Künsten, hrsg. von K. Ebeling, S. Günzel, Kadmos, Berlin 2009, s. 17-18. 
socjologa literatury wiedza dotycząca historii i konstrukcji zasobu może się okazać kluczowa. Trzecią istotną kwestią poza regulaminem korzystania z zasobów są praktyki przyjęte w pracy. O dostępności, a tym samym widoczności dokumentów decyduje m.in. konieczność uzyskania pisemnej zgody od żyjących autorów, a interpretacja dokumentów przez użytkownika odbywa się nierzadko we współpracy z archiwariuszami występującymi w funkcji ekspertów.

(3) Porządek archiwum powstaje w końcu na trzecim, dotychczas nieomawianym poziomie interpretacyjnym, który można określić mianem praktyk wystawienniczych. Brak szerszego namysłu teoretycznego współgra w tym wypadku ze stosunkowo młodym wiekiem samego fenomenu: idea powiązania pracy archiwistycznej, badawczej i muzealniczej pojawiła się w niemieckim obszarze językowym na początku bieżącego stulecia ${ }^{45}$; odtąd towarzyszy jej spore zainteresowanie i wsparcie ze strony twórców polityki naukowej ${ }^{46}$. Do grona nielicznych osób formułujących metodologiczne perspektywy praktyk prezentacji literatury w przestrzeni muzealnej należy zaliczyć Heike Gfrereis. Wobec przekonania, jakoby teksty literackie pozostawały w swojej abstrakcyjności „niewystawialne”, a podejmowane próby oferowały zaledwie „surogat" literatury ${ }^{47}$, Gfrereis pisze o wystawie jako „metodzie naukowej hermeneutyki" $i$,akcie podwójnej poesis"48. Jeśli bowiem sam archiwalny zasób jest konstrukcją, to ekspozycja wyjętych z niego tekstów jest konstrukcją drugiego rzędu, obejmującą wybór materiału, jego zestawienie i rozlokowanie przestrzenne, oprawę graficzną w wersji papierowej i cyfrowej, w końcu przygotowanie paratekstów. Wystawa redukuje kompleksowość

45 H. Bredekamp Kein Museum ohne Forschung - keine Forschung ohne Sammlung , "Museumkunde" 2001 Nr. 66 (2), s. 101-105.

46 W opublikowanych w 2011 roku wytycznych Wissenschaftsrat, najważniejszego federalnego organu doradczego w obszarze polityki naukowej, zbiory archiwalne/muzealne określono mianem kluczowej „infrastruktury badawczej” i zalecono zrównanie przygotowania wystaw poświęconych m.in. literaturze z innymi formami działalności publikacyjnej podlegającymi ewaluacji (Empfehlungen zu wissenschaftlichen Sammlungen als Forschungsinfrastrukturen, Wissenschaftsrat, Berlin 2011).

47 B.J. Dotzler Die Wörter und die Augen. Zur Un-Möglichkeit der Visualisierung, w: Wort-Räume, Zeichen-Wechel, Augen-Poesie. Zur Theorie und Praxis von Literaturausstellungen; mit einer Dokumentation der Ausstellung "Wie stellt man Literatur aus? Sieben Positionen zu Goethes «Wilhelm Meister»", Wallstein, Göttingen 2011, s. 45, 50).

48 H. Gfrereis Ausstellung, w: Handbuch Archiv, s. 225. 
masy archiwalnej, zamienia wielogłosowość dokumentów w uprzednio zdefiniowaną „atmosferę", przez co sama jest „czynem poetyckim"49.

Chaos i porządek archiwum jest zatem zagadnieniem nie tyle metaforycznym, ile czysto praktycznym. Świadomość rozmaitych poziomów i etapów interpretujących materiał dokumentacyjny każe nam pamiętać, że archiwum jest aktywnym producentem przeszłości, medium historii, instrumentem uwidocznienia i ukrycia.

\section{Abstract}

\section{Paweł Zajas}

ADAM MICKIEWICZ UNIVERSITY (POZNAŃ), UNIVERSITY OF PRETORIA

The Chaos and Order of the Archive

Zajas discusses the selection and interpretation of documents in the context of the literary archive, which emerged as an institution at the end of the nineteenth century. First he examines the internal and external factors that impact the shape of the author's estate. Next he analyses the transposition of the publisher's archive to the form of the literary archive. In the conclusion he highlights three levels of interpretive interventions that take place in the archive. An awareness of their scope is key especially for the sociology of literature.

\section{Keywords}

literary archive, publisher's archive, writer's estate, Nachlass, Vorlass 